\title{
Declining Proportion of Foreign Exchange Earnings from Tourism to Gross Domestic Product in Nepal
}

\author{
Deo Narayan Sutihar
}

\begin{abstract}
This article attempts to estimate annual declining trend of proportion of foreign exchange earnings from tourism to Gross Domestic Product (GDP) in Nepal and test the significance of declining trend of this ratio using time series data of 20 years from FY 1991/92 to FY 2010/11l. It has been that the declining trend of foreign exchange earnings from tourism to GDP ratio is significant. The inequality in the distribution of foreign exchange earnings from tourism to GDP ratio is tolerable.
\end{abstract}

Keywords: (declining trend, foreign exchange earnings, Gini coefficient).

\section{Introduction}

Nepal is a country of full diversities regarding natural, cultural, ethnic community and social heritages, flora and fauna, pilgrimage, etc. So it has great potentialities to develop tourism. The promotion of tourism in Nepal in the true sense started more or less only from the beginning of the 1960's. Since the First Five Year Plan and onwards the government of Nepal has been adopted an integrated approach of increasing the number of tourists arrivals and length of stay, earning exchanges, creating employment opportunities, sustainable economic growth, alleviation of poverty and reduction of regional imbalances through tourism (Gurung: 2010, 106).

Tourism is an important industry and it is gaining a growing recognition in the world. It is smokeless industry. Developed countries have already benefited from tourism while developing countries are gradually benefiting. Tourism industry generates substantial benefits for both host countries and tourist's home country. It is the main source of foreign exchange earning and an important factor in the development of industries and international trade. It plays an important role in economic and technological development of nations. It also serves to stimulate the development of basic infrastructure, contributes to the growth of domestic industries, attracts foreign investment, facilities the transfer of technology and information (Srivastava and Baral: 2010, 1-2).

Most of the tourists arriving to Nepal are found to pursuing recreation, trekking and mountaineering. On the tourists visiting Nepal in calendar year 2011, 53.7 percent visited for tours/travels, 11.77 percent for trekking/ mountaineering, 8.7 percent for pilgrimage, 4.1 percent for recreation, 2.4 percent for trade, 3.3 percent for formal visit, 
The contribution of tourism industry to GDP was 3.6 percent in FY 1991/92 and 1.4 percent in FY 2006/07 (MOF: 2009, 112), which was reached to 1.8 percent in FY 2010/11 (MOF: 2069, 152).

Ministry of Tourism and Civil Aviation, in collaboration with concerned industry entrepreneurs, and Nepal Tourism Board, has issued Nepal Tourism Vision 2020. Under this, vision, target, objectives and strategies have been set to attract 2 million tourists in 2020 (MOF: 2009, 111).

Nepal is a small country but full of diversities regarding natural, cultural, ethnic communities and historical heritages, which attract religious, sports, endemic tourists to visit. It is a tourist destination with tremendous tourism potentialities. The relevant literature regarding the foreign exchange earnings from tourism to GDP ratio in Nepal is not available. However, some scattered studies have exhibited dim glimpse (Poudyal: 2012, Upadhyay: 2013, Gurung: 2010, Sharma: 2013, Shakya: 2008) about the very cotext.

\section{Objective and Limitation}

The main objective of this paper is to exhibit the declining ratio of foreign exchange earnings from tourism to GDP in Nepal. In addition, the specific objective is to estimate annual declining rate of this ratio and to test this declining rate is significant or not. However, the findings of this paper should be cautiously and carefully used because the analysis is made only for 20 years. The data before 1991/92 have not been considered to analyze due to time constraint.

\section{Data and Methods}

This paper is based on the secondary data annually published by the Government of Nepal. The Economic Survey Fiscal Year 2005/06, Fiscal Year 2008/09 and Fiscal Year 2068/69 of Nepal are the only sources of statistical data for this study (Table-1)

The data have been analyzed with the help of different statistical tools like ratio, percentage, linear equation for estimating the annual declining rate of foreign exchange earnings from tourism to GDP ratio, its standard error, to test significance of this ratio through t-statistic.

The estimating linear equation of the declining rate of proportion of foreign exchange earnings from tourism to GDP in Nepal of 20 years from 1991/92 to 2010/11 has been used in form of $Y_{t}=b_{0}+b_{1} X_{t}$, where, $Y_{t}=$ foreign exchange earnings from tourism to GDP ratio, $X_{t}=$ time variable, $b_{0}$ and $b_{1}=$ parameters, $b_{0}$ stands for Y-intercept and $b_{1}$ for declining rate of foreign exchange earnings from tourism to GDP ratio or slope of trend line (Singh, Parashar and Singh:1977, 66).

For these parameters, two normal equations of least squares method have been used:

$\sum \mathrm{Y}_{\mathrm{t}}=\mathrm{nb}_{0}+\mathrm{b}_{1} \sum \mathrm{X}_{\mathrm{t}}$ and $\sum \mathrm{X}_{\mathrm{t}} \mathrm{Y}_{\mathrm{t}}=\mathrm{b}_{0} \sum \mathrm{X}_{\mathrm{t}}+\mathrm{b}_{1} \sum \mathrm{X}_{\mathrm{t}}^{2}$ 


$$
S_{y x}=\sqrt{\frac{\sum e_{t}^{2}}{n-k}} \text { has been used to arrive standard error of estimate, where, } n \text { and } k \text { stand }
$$

for number of years and number of parameters respectively. The statistical hypotheses for parameter $b_{1}$ has been set up and tested. The null hypothesis $H_{1}: b_{1}=0$ i.e., foreign exchange earnings from tourism to GDP ratio is not significant against alternative hypothesis $\mathrm{H}_{1}: \mathrm{b}_{1} \neq 0$, i.e., foreign exchange earnings from tourism to GDP ratio is significant at $5 \%$ level if significance with $\mathrm{n}-\mathrm{k}$ degrees of freedom. The $\mathrm{t}$-test is used to test the significance $b_{1}$ as:

$$
\mathrm{t}=\frac{\mathrm{b}_{1}}{\sqrt{\frac{\sum \mathrm{e}_{\mathrm{t}}^{2}}{\mathrm{n}-2}\left(\frac{1}{\sum \mathrm{x}_{\mathrm{t}}^{2}}\right)}} \text {, where, } \sum \mathrm{e}_{\mathrm{t}}^{2}=\sum\left(\mathrm{Y}_{\mathrm{t}}-\hat{\mathrm{Y}}_{\mathrm{t}}\right)^{2} \text { and } \sum \mathrm{x}_{\mathrm{t}}^{2}=\sum \mathrm{X}_{\mathrm{t}}^{2}-\mathrm{n} \overline{\mathrm{X}}^{2}
$$

The Gini coefficient is used to measure the inequality in distribution of the proportion of foreign exchange earnings from tourism to GDP in 20 years and defined as:

$$
\mathrm{Gc}=\frac{1}{(100)^{2}}\left[\sum \mathrm{X}_{\mathrm{i}} \mathrm{Y}_{\mathrm{i}+1}-\sum \mathrm{X}_{\mathrm{i}+1} \mathrm{Y}_{\mathrm{i}}\right]
$$

Where, $X_{i}=\%$ of cumulative years

$\mathrm{Y}_{\mathrm{i}}=\%$ of total proportion of foreign exchange earnings from tourism to GDP

$\mathrm{i}=1,2, \ldots \ldots, \mathrm{n}$ (Sutihar: 2010, 171).

\section{Results and Discussion}

This paper evaluates the declining proportion of foreign exchange earnings from tourism to GDP in Nepal, which ranges from 1.4 percent in FY 206/07 to 4.1 percent in 1994/95. The ratio has been found oscillating in different years. The annual declining rate of foreign exchange earnings from tourism to GDP ratio has been also estimated through the analysis of time series data of 20 fiscal years from 1991/92 to 2010/11. The estimated equation of straight line is $\hat{Y}_{t}=4.0473-0.1145 X_{t}$, which shows that annual declining rate of proportion of foreign exchange earnings from tourism to GDP in Nepal is 0.4511 percent during study period (Table-1). The trend of foreign exchange earnings from tourism to GDP ratio in Nepal is declining continuously during study period (Fig.1).

The standard error of estimate is 0.4562 percent. The calculated value of $\mathrm{t}_{(\mathrm{b} 1)}=15.401$, which is greater than critical value of $t=2.101$ (Two tailed test) at 5 percent level of significance with 18 degrees of freedom. This exhibits that null hypothesis is rejected and alternative hypothesis is accepted. Hence, it is concluded that the declining rate of foreign exchange earnings from tourism to GDP ratio is significant.

The Gini coefficient is 0.1702 , which shows that there is 17.02 percent inequality in the distribution of proportion of foreign exchange earnings from tourism to GDP in Nepal. 
Fig. 1: Trend Line \& Actual Value of Foregin Exchange Earnings from Tourism to GDP ratio (in \%)

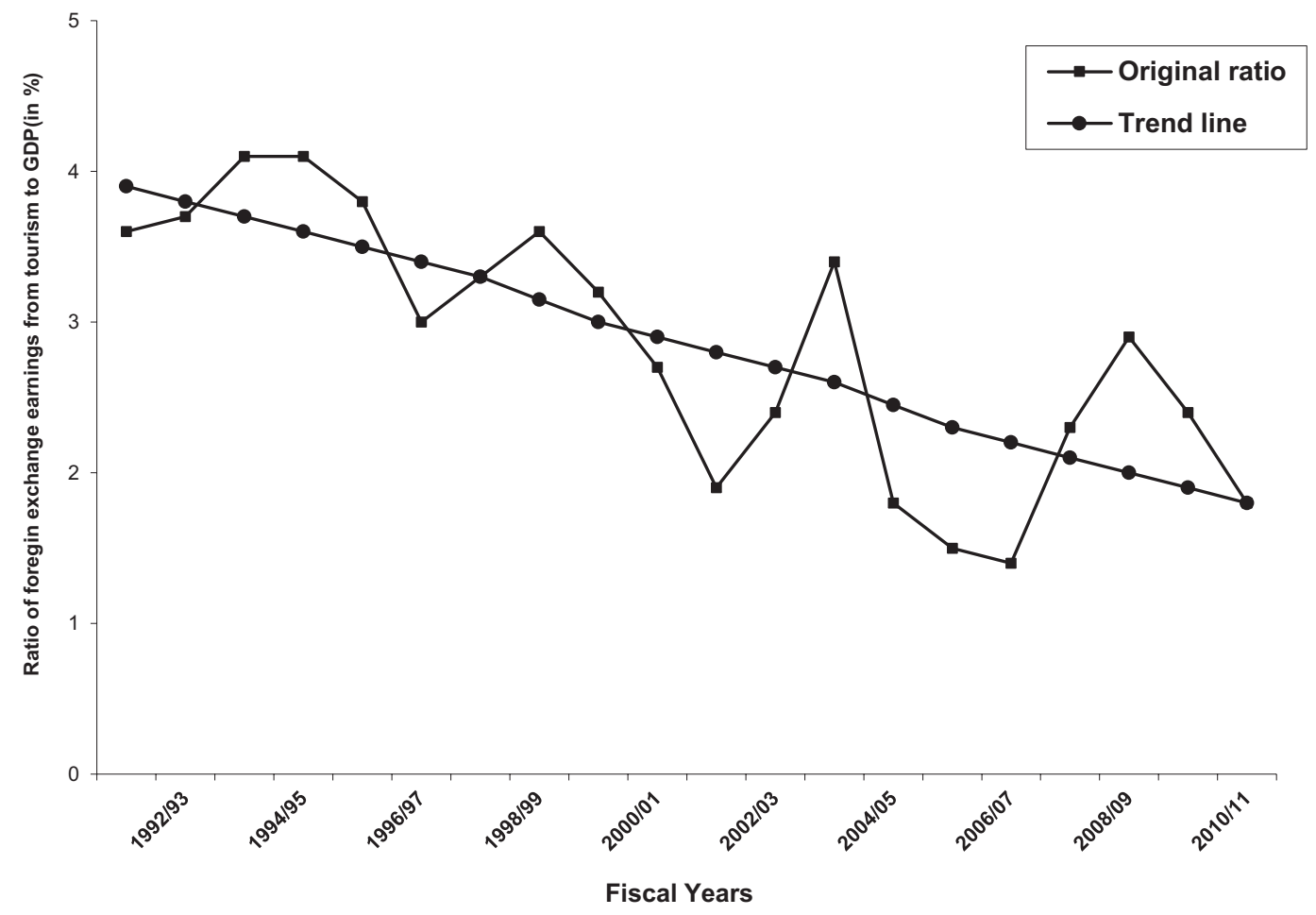

\section{Conlusion}

From the analysis of data, it is obvious that proportion of foreign exchange earnings from tourism to GDP has been oscillated during study period. The annual declining rate of foreign exchange earnings from tourism to GDP ratio is significant. This declining is damping slowly. It is obvious that if this declining rate will continue, foreign exchange earnings from tourism to GDP ratio will be nil in FY 2025/26. After the fateful Indian Airlines hi-jack on 24 December 2000, the tourist industry started facing problems in sequence, which was followed by Hritik Roshan problem, Royal massacre, SARS, Bird flue along with ongoing political instability and Maoist insurgency, etc. are the main reason to decline the trend of tourist arrival in Nepal. Hence, it is recommended that more efforts should be made to improve swiftly the foreign exchange earnings from tourism by framing vision, target, objectives and strategies of proper policy and programmes in forthcoming time. Nepal is a country of full diversities regarding natural, cultural, ethnic communities and social heritages, flora and fauna, pilgrimage. So it has great potentialities to develop tourism. The inequality in the distribution of foreign exchange earnings from tourism to GDP ratio is low, which exhibits that inequality in the distribution foreign exchange earnings from tourism to GDP ratio is tolerable.

Table-1: Proportion of Foreign Exchange Earnings from Tourism to GDP (in \%) 
Janapriya Journal of Interdisciplinary Studies, Vol. 2, No.1 (December 2013)

\begin{tabular}{|c|c|c|c|c|c|}
\hline $\begin{array}{l}\text { FiscalYear } \\
\left(X_{t}\right)\end{array}$ & $\begin{array}{l}\text { GDP } \\
\text { (Rs.in million) }\end{array}$ & $\begin{array}{l}\text { Foreign exchange } \\
\text { earning from } \\
\text { tourism (Rs. in } \\
\text { million) }\end{array}$ & $\begin{array}{l}\text { As } \% \text { of GDP } \\
\left(Y_{t}\right)\end{array}$ & $\begin{array}{l}\hat{Y}_{t}= \\
4.0473 \\
-0.1145 \mathrm{X}_{\mathrm{t}}\end{array}$ & $e_{t}$ \\
\hline 1991/92(1) & 149487 & 15016.9 & 3.6 & 3.9 & -0.3 \\
\hline 1992/93(2) & 171492 & 5966.0 & 3.7 & 3.8 & -0.1 \\
\hline 1993/94(3) & 199272 & 8251.7 & 4.1 & 3.7 & 0.4 \\
\hline 1994/95(4) & 219175 & 8973.2 & 4.1 & 3.6 & 0.5 \\
\hline $1995 / 96(5)$ & 248913 & 9521.2 & 3.8 & 3.5 & 0.3 \\
\hline 1996/97(6) & 280513 & 8523.0 & 3.0 & 3.4 & -0.4 \\
\hline $1997 / 98(7)$ & 300845 & 9881.6 & 3.3 & 3.3 & 0 \\
\hline 1998/99(8) & 342036 & 12167.8 & 3.6 & 3.1 & -0.5 \\
\hline 1999/00(9) & 379488 & 12073.9 & 3.2 & 3.0 & 0.2 \\
\hline 2000/01(10) & 441519 & 11717.0 & 2.7 & 2.9 & -0.2 \\
\hline 2001/02(11) & 459443 & 8654.3 & 1.9 & 2.8 & -0.9 \\
\hline $2002 / 03(12)$ & 492231 & 11747.7 & 2.4 & 2.7 & -0.3 \\
\hline 2003/04(13) & 536749 & 18147.4 & 3.4 & 2.6 & 0.8 \\
\hline 2004/05(14) & 589412 & 10464.0 & 1.8 & 2.4 & -0.6 \\
\hline 2005/06(15) & 654084 & 9556.0 & 1.5 & 2.3 & -0.8 \\
\hline 2006/07(16) & 728178 & 10125.0 & 1.4 & 2.2 & -0.8 \\
\hline 2007/08(17) & 815658 & 18653.0 & 2.3 & 2.1 & 0.2 \\
\hline 2008/09(18) & 988272 & 27960.0 & 2.9 & 2.0 & 0.9 \\
\hline 2009/10(19) & 1193679 & 28139.0 & 2.4 & 1.9 & 0.5 \\
\hline 2010/11(20) & 1369430 & 28633.0 & 1.8 & 1.8 & 0 \\
\hline
\end{tabular}

Sources: Data have been adapted and calculated from Economic Survey Fiscal Year 2005/06, Table 1.2, 2, Economic Survey Fiscal Year 2008/09, Table 8.16, 78 and Economic Survey Fiscal Year 2068/69, Table 9.4, 89.

\section{References}

Gurung, J.B. (2010). "Tourism in Nepal: Arrivals, Earnings and Employment", Economic Literature, Vol.IX, April 2010, Pokhara: Department of Economics, Prithvi Narayan Campus, Tribhuvan University, pp.105-115.

Ministry of Finance (2006). Economic Survey Fiscal Year 2005/06, Kathmandu: Ministry of Finance, Government of Nepal.

------(2009). Economic Survey Fiscal Year 2008/09, Kathmandu: Ministry of Finance, Government of Nepal.

------(2069). Economic Survey Fiscal Year 2068/69, Kathmandu: Ministry of Finance, Government of Nepal.

Poudyal, S. (2012). "Does Tourims Really Matter for Eccoomic Growth? Evidence from Nepal", NRB Economic Review, Vol. 24, No.1, Kathmandu: Nepal Rastra Bank, pp.48-66.

Shakya, K. (2008). "Tourism-Yesterday, Today and Tomorrow", Rural Tourism, ed. R. 
Janapriya Journal of Interdisciplinary Studies, Vol. 2, No.1 (December 2013)

P. Upadhyay, Kathmandu: Sunlight Publication, pp.31-42.

Sharma, Om P. (2013).The System of Tourism Development Planning in Nepal (An Integrated Approach), Second ed., Kathmandu: Nawaraj Pandey, Anand Chand, Saraswati Sharma

Singh, S.P., Parashar, A.K. and Singh, H.P. (1977). Econometrics and Mathematical Economics, New Delhi: S. Chand and Company Limited.

Srivastava, N.L. and Baral, P. (2010). "State and Prospects of Tourism Development in Lekhnath Municipality, Kaski", Economic Literature, Vol.IX, August 2010, Pokhara: Department of Economics, Prithvi Narayan Campus, Tribhuvan University, pp.1-12.

Sutihar, D.N. (2010).Quantitative Techniques, Kathmandu: Pairavi Prakashan. 